the magma(s) or post emplacement alteration of the rocks by circulating groundwater (Barrett and Berg, 1975).

The Spanish lamproites show marked REE differences from the $W$. Australian suites and from "typical" kimberlites (Figs. 2 and 3 ). The REE pattern could be interpreted to indicate magma derivation from a more depleted source than that of kimberlite but with a similar (metasomatic) overprint of LREE and incompatible elements. The comparatively high HREE content suggests derivation from shallower mantle depths than that in which garnet is stable and correlates with observed lherzolite xenoliths containing spinel rather than garnet. A-ve Eu anomaly persists through the jumillite, cancarix-type, verite and fortunite suites. This feature may be due to removal of plagioclase from the magma or be present in the source region, particularly that of the met asomatising fluids ( $c f$. Hawkesworth and Vollmer, 1979). It is another reason for regarding the Spanish rocks as genetically distinct from the Australian 1 amproite - ' $:$ i.ar i $\{$ - suite.
ACKNOWLEDGEMENTS : We thank David Gellatly and Amax Exploration for assistance in the field in Western Australia and for specimens of the Big Spring kimberlitic rock; David Rex for the age determination; Alan Grey for some lamproite analyses; and John Lewis and Richard Jones for helpful comments. fitkinson, W. J. 1982: Trans. Inst. Mining Metal. (in press).

Barrett, D. R. and Berg, G. W. 1975: Phys. Chem. Earth, 9, 619 - 636

Borley, G. D. 1967: Miner. Mag. 36, $364-379$

De Paolo, D. P. and Wasserburg, C. J. 1979: Geochem. Cosmochim. Acta, 43, 615-628

Derrick, G. M., and Gellatly, D. C. 1972: Extract No. 10. Bul1. 135, Bureau Mineral. Res. Canberra. Fuster, J. M., Gastesi, P., and Fermoso, M. L. 1967: Estudios Geologicos, 23, $35-69$.

Gurney, J. J., and Ebrahim, S. 1973: (In P.H. Nixon, ed.) Lesotho Kimberlites. Lesotho Nat. Devel. Corp. Maseru, Lesotho.

Hawkesworth, C. J., and Vollmer, R. 1979: Contrib. Mineral. Petrol. 69, $151-165$.

Johannsen, A. 1938: A descriptive petrography of igneous rocks. The University of Chicago Press.

Niggli, P. 1923: Gesteins-und mineralprovinzen, Bd. 1., Berlin.

O'Nions, R. K., Carter, S. R., Evenson, N. M. , and Hamilton, P. J. 1979: Ann. Rev. Earth Planet. Sci. $\underline{7}, 11-38$

Powell, J. L., and Be11, K. 1970: Contr. Mineral Petrol. 27, $1-10$.

Prider, R. T. 1960: J. Geol. Soc. Aust. 6, 71-118.

Rogers, N. W. 1979: Trace element analysis of kimberlites and associated rucks and zenoliths. Ph.D. thesis, Univ. London.

Troger, W. E. 1935: Spezielle Petrographie de Eruptivgesteine, Berlin. $360 \mathrm{pp}$.

Wade, A., and Prider, R. T. 1940: nuart. J. geol. Soc. Lond. $96,39-98$.

Nalsh, J. N., Buckley, F., and Barker, J. 1981: Chem. Geol. 33, $141-153$.

We $11 \mathrm{man}$, P. 1971: J. Geol. Soc. Aust. 19, $471-474$.

\title{
MEGACRYSTS FROM THE HAMILTON BRANCH KIMBERLITE PIPE, KENTUCKY : DISCRETE NODULES AND CUMULATE ROCKS
}

\section{Daniel J. SCHULZE,}

Geosciences Department, The University of Texas at Dallas, Box 688, Richardson, Texas. U.S.A. 75080

The southeasternmost kimberlite pipe in Elliot County, Kentucky, the Hamilton Branch pipe, contains a wide variety of mantle-derived material. Garnet 1herzolites and $\mathrm{Cr}$-poor discrete nodules (terminology of Eggler et al, 1979) are most abundant. Also present is a group of cumulate rocks with "discrete nodule" characteristics and fine-grained intercumulus material. This group has been termed the Na-rich suite, based on the high $\mathrm{Na}_{2} \mathrm{O}$ content of the diopside.

Monomineralic garnets, diopsides, and ilmenites dominate the $\mathrm{Cr}$-poor suite. Enstatite, olivine, and phlogopite are rare due to near surface weathering. Large olivines are absent, though mosaic dunites are considered members of the $\mathrm{Cr}$-poor suite, based on rare association with $\mathrm{Cr}$-poor garnet and diopside. There is no overlap in olivine composition of dunites (Fo 88-89) and garnet Iherzolites (Fo 89.5-93).

The simple concept of magnesian, ilmenite-free discrete silicates distinct from an Fe-rich "ilmenite association" (of lower T, based on $\mathrm{Ca} /(\mathrm{Ca}+\mathrm{Mg}+\mathrm{Fe}$ ) of $(p x)$ does not apply to this suite. Ilmenite is present throughout almost the entire compositional range of each silicate (Fig. 1) and its composition is related to its texture. Five textural groups of ilmenite-bearing discrete nodules have been recognized: (1) monomineralic ilmenite nodules, generally with porphyroclastic to mosaic texture, (2) ilmenitedominated nodules similar to (1) but containing small silicate inclusions, (3) silicate dominated nodules. with tiny included ilmenite, (4) Na-rich suite nodules (see below), and (5) graphic cpx/ilm intergrowths. Except for (4) these seem to form a chemically coherent suite.

The Kentucky ilmenites are magnesian (8-15.2\% Mg0) and rich in ferric iron (6-16 mole $\% \mathrm{Fe}^{+3}$ ) and approximately form a parabolic curve (Haggerty, 1975) on a $\mathrm{Cr}_{2} \mathrm{O}_{3} / \mathrm{MgO}$ plot (Fig. 2). However, the low $\left(\mathrm{r}_{2} \mathrm{O}_{2}\right.$ "trough" is displaced to a higher value $(12 \% \mathrm{Mg}())$ than in many other suites. This parabola is comprised of segments corresponding to the five textural groups. Silicate-dominated nodules (3) fall on the $\mathrm{Mg}, \mathrm{Cr}-\mathrm{rich}$ limb, ilmenite-dominated nodules (2) fall in the trough, and graphic cpx/ilm intergrowths (5) bridge the two. The MgO-poor limb is exclusively monomineralic ilmenites ( 1 ), which are also found throughout the curve. Approximately $40 \%$ of the samples in this group are more iron-rich $(\mathrm{Mg} /(\mathrm{Mg}+\mathrm{Fe})$ - 0.38$)$ than any ilmenites associated with silicates. Ilmenites from nodules not related to the Cr-poor suite (the Na-rich suite and an ilmenite garnet therzolite $\left(2.7 \% \mathrm{Cr}_{2} \mathrm{O}_{3}\right.$, $15.5 \% \mathrm{MgO}$ ) also plot on this parabola.

Silicates of Group 3 are as magnesian (and subcalcic in the case of $\mathrm{cpx}$ ) as ilmenite-free silicates (Fig. 1). Those from ilmenite dominated nodules (2)

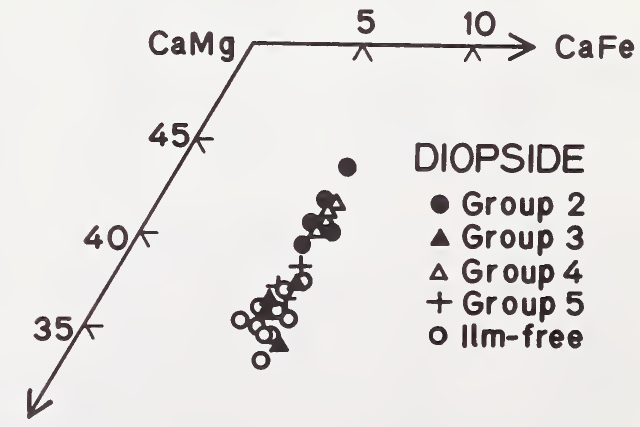


show Fe-enrichment only slightly greater than analytical uncertainty. Schulze and Hoover (1982) have shown that precipitation of ilmenite exerts strong control on megacryst fractionation trends, even to the point of causing Mg-enrichment. The almost constant $\mathrm{Mg} /(\mathrm{Mg}+\mathrm{Fe})$ trend (Fig. 1) is therefore probably due to precipitation of abundant ilmenite. This is consistent with the observation that ilmenite is present throughout almost the entire range of silicate compositions.

Three groups of discrete phlogopite have been identified. Two are iron-rich $(\mathrm{Mg} /(\mathrm{Mg}+\mathrm{Fe})=0.86-0.88)$ and are separated by $\mathrm{TiO}_{2}$ content $(0.5-0.6 \mathrm{wt} \%$ and $1.3-1.6 \mathrm{wt} \%)$. The third group is magnesian $(\mathrm{Mg} /(\mathrm{Mg}+$ $\mathrm{Fe})=0.914)$ and $\mathrm{TiO}_{2}$-poor $(\sim 0.4 \mathrm{wt} \%)$. In one sample of this group the mica is attached to a low T diopside $\left(\mathrm{Ca} /(\mathrm{Ca}+\mathrm{Mg}) \cong 0.50\right.$ ) poor in $\mathrm{Al}_{2} \mathrm{O}_{3}$ ( $\sim 0.3$ wt \%) and rich in $\mathrm{Cr}_{2} \mathrm{O}_{3}(\sim 1.9 \mathrm{wt} \%)$. Also included in this diopside is $\mathrm{K}$-richterite, chromite $(\mathrm{Cr} /(\mathrm{Cr}+\mathrm{Al})=0.94$, $\mathrm{Mg} /(\mathrm{Mg}+\mathrm{Fe})=0.32)$, abundant serpentine after olivine, and calcite and phlogopite-bearing polymineralic inclusions of the type Schulze (1981) considered to represent liquid inclusions, and be indicative of an igneous origin for the host. Neither of the iron-rich groups has been definitely linked with the Cr-poor nodules. The affiliation of the Mg-rich group is also uncertain, although similarities exist with both the MARID suite (amphibole + phlogopite + diopside assemblage and low $\mathrm{Al}_{2} \mathrm{O}_{3}$ content of the diopside) and the $\mathrm{Cr}-\mathrm{rich}$ suite of discrete nodules (high $\mathrm{Cr}_{2} \mathrm{O}_{3}$ content of diopside and presence of chromite).

The Na-rich suite consists of aggregates of large $(>.5 \mathrm{~cm})$ diopside, ilmenite, and lesser garnet and orthopyroxene with cumulus textures and fine-grained intercumulus material (olivine, serpentine, phlogopite, aluminous pyroxenes, spinel, kaersutite). Representative compositions are presented in Tables 1 and 2.

Table 1

\section{Analyses of Na-rich suite}

\begin{tabular}{lrrrr} 
& $\mathrm{Cpx}$ & $\mathrm{Opx}$ & $\mathrm{Ga}$ & \multicolumn{1}{c}{$\mathrm{I} 1 \mathrm{~m}$} \\
$\mathrm{Na}_{2} \mathrm{O}$ & 3.52 & 0.24 & - & - \\
$\mathrm{MgO}^{2}$ & 15.15 & 33.87 & 20.66 & 13.64 \\
$\mathrm{Al}_{2} \mathrm{O}_{3}$ & 4.44 & 0.96 & 22.90 & 1.16 \\
$\mathrm{SiO}_{2}$ & 55.15 & 56.92 & 41.83 & 0.15 \\
$\mathrm{CaO}$ & 16.46 & 0.41 & 3.52 & - \\
$\mathrm{TiO}_{2}$ & 0.41 & 0.19 & 0.34 & 53.63 \\
$\mathrm{Cr}_{2} \mathrm{O}_{3}$ & 0.96 & 0.15 & 1.07 & 1.24 \\
$\mathrm{MnO}$ & - & 0.15 & 0.42 & 0.35 \\
$\mathrm{FeO} *$ & 4.15 & 6.64 & 9.56 & 30.24
\end{tabular}

$\begin{array}{lllll}\text { Total } & 100.24 & 99.53 & 100.30 & 100.41\end{array}$

\section{Table 2}

Analyses of intercumulus minerals and bulk

Amph Phlog Sp CpX Opx 01 Bulk

$\begin{array}{lllllllr}\mathrm{Na}_{2} \mathrm{O} & 2.36 & 0.26 & - & 0.96 & 0.25 & - & 0.8\end{array}$

$\begin{array}{lrrrrrrr}\mathrm{Na}_{2} \mathrm{O} & 2.36 & 0.26 & - & 0.96 & 0.25 & - & 0.8 \\ \mathrm{MgO} & 14.62 & 18.04 & 22.05 & 13.62 & 30.82 & 47.89 & 20.9\end{array}$

$\begin{array}{llllrrrr}\mathrm{Al}_{2} \mathrm{O}_{3} & 15.38 & 14.94 & 60.57 & 7.46 & 2.96 & - & 8.0\end{array}$

$\begin{array}{llllllll}\mathrm{SiO}_{2} & 40.25 & 38.51 & - & 49.44 & 54.89 & 39.63 & 40.1\end{array}$

$\begin{array}{rrrrrrrr}\mathrm{K}_{2} \mathrm{O} & 1.76 & 9.41 & - & - & - & - & 1.6 \\ \mathrm{CaO} & 11.25 & - & - & 22.14 & 1.28 & 0.15 & 5.6\end{array}$

$\begin{array}{lrllrlll}\mathrm{CaO} & 11.25 & - & - & 22.14 & 1.28 & 0.15 & 5.6 \\ \mathrm{TiO}_{2} & 5.86 & 8.48 & 0.92 & 1.90 & 0.46 & - & 1.9\end{array}$

$\begin{array}{llllllll}\mathrm{Cr}_{2} \mathrm{O}_{3} & 0.29 & 0.54 & 1.96 & 0.26 & 0.68 & - & 0.3\end{array}$

$\begin{array}{lrrrrrrr}\mathrm{MnO} & 0.18 & 0.10 & 0.18 & 0.20 & 0.18 & (0.3 \mathrm{NiO}) & - \\ \mathrm{FeO}^{*} & 6.57 & 6.31 & 14.46 & 4.40 & 7.08 & 11.31 & 9.1\end{array}$

$\begin{array}{llllllll}\text { Total } & 98.52 & 97.49 & 100.14 & 100.39 & 98.61 & 99.28 & 88.3\end{array}$

The cumulus phases are distinct from garnet lherzolite minerals, Cr-rich and $\mathrm{Cr}$-poor discrete minerals, and megacrysts from other alkalic rocks. (Though Boyd and Nixon (1973) described a similar rock (1680B) as a cumulate, they did not report intercumulus material). The diopside is chemically the most distinctive cumulus mineral in its high $\mathrm{Na}_{2} \mathrm{O}$ content $\left(3.5-4 \% \mathrm{Na}_{2} \mathrm{O}\right)$. The garnet is characterized by its low $\mathrm{TiO}_{2}$ and $\mathrm{CaO}$ contents $(0.3,3.5 \%)$, and, while the enstatite is as magnesian as some lherzolite opx's (mg .905), it has $\mathrm{Ti}>\mathrm{Cr}$, unlike those from 1herzolites. The ilmenites

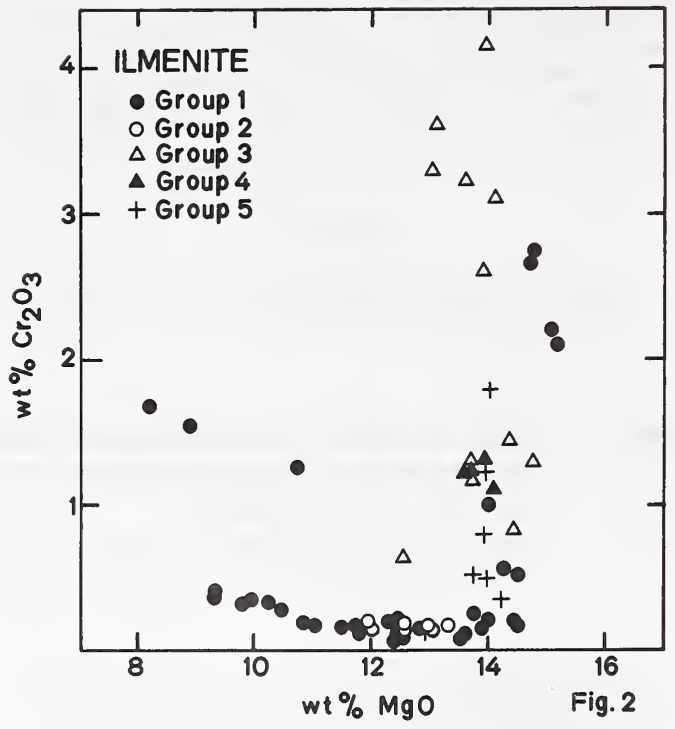

form a small cluster on the parabola near $\mathrm{Mg} 014 \%$, $\mathrm{Cr}_{2} \mathrm{O}_{3} 1.2 \%$.

Though broadly similar to kimberlites in bulk composition (broad beam probe scan), the intercumulus material is notably higher in $\mathrm{Na}$ and $\mathrm{Al}$ (Table 2). Mineralogically it is quite unlike kimberlites. Though the phlogopite is aluminous, it is very high in $\mathrm{TiO}_{2}$. The kaersutite is also $\mathrm{Ti}$ and $\mathrm{Mg}-\mathrm{rich}$, more so than most kaersutites from alkali basalt occurrences. Kaersutite is almost unknown from kimberlites (Boyd et al, 1981); Ti-poor pargasites and richterites are the rare kimberlitic amphiboles. The spinel is unusually Al-rich and Ti-poor for kimberlitic spinels. The aluminous pyroxenes (up to $12 \mathrm{wt} \%$ $\mathrm{Al}_{2} \mathrm{O}_{3}$ in $(p x)$ are unusual, as is the apparent absence of calcite. This alkaline ultrabasic liquid may be a deep-seated lamprophyre.

Equilibration temperatures from Lindsley and Dixon (1975) and pressures from opx alumina isopleths of Perkins and Newton (1980) have been estimated for appropriate assemblages. Discrete $\mathrm{Cr}$-poor diopsides ( \pm ga, ilm, ol) have the highest temperatures $\left(1400^{\circ}\right.$ $\mathrm{C}-1290^{\circ} \mathrm{C}$ ), followed at successively lower $\mathrm{T}^{\prime} \mathrm{s}$ by deformed garnet lherzolites $\left(1330^{\circ}-1270^{\circ} \mathrm{C}\right)$, graphic $\mathrm{cpx} / \mathrm{ilm}$ intergrowths $\left(1330^{\circ}-1270^{\circ} \mathrm{C}\right)$, both overlapping the discrete diopsides, the Na-rich suite $\left(1210^{\circ}\right.$ $\left.-1145^{\circ} \mathrm{C}\right)$, tiny $\mathrm{cpx}$ 's in ilmenite $\left(1210^{\circ}-1100^{\circ} \mathrm{C}\right)$, and the coarse garnet 1 herzolites $\left(1150^{\circ}-1090^{\circ} \mathrm{C}\right)$. Estimated pressures fall in a very limited range (45-50 $\mathrm{kb}$ ) for all cpx-opx-ga assemblages (garnet 1herzolites and $\mathrm{Na-rich}$ suite).

The coarse garnet lherzolites represent a "steady state" at about $1100^{\circ} \mathrm{C}$ and $45-50 \mathrm{~kb}$. These are interpreted to have been intruded by a higher $\mathrm{T}(\sim$ $1200^{\circ} \mathrm{C}$ ) alkalic ultrabasic magma which differentiated in place yielding the Na-rich suite of cumulates and a residual intercumulus magma. Like the coarse 1herzolites, these cumulates are essentially undeformed. The $\mathrm{Cr}$-poor discrete nodules crystallized in a sequence similar to that proposed for the Lekkerfontein suite (Robey and Gurney, 1979), where initially only silicates precipitated, followed by graphic clinopyroxene/ilmenite intergrowths, and then ilmenite-dominated nodules. The final stage, not recorded in silicate compositions, is the precipitation of abundant iron-rich ilmenite. The Kentucky suite differs from this, and most other suites, in having ilmenite present throughout the range of silicates and, therefore lacking the strong iron-enrichment of low temperature nodules. The overlap of higher $\mathrm{T}$ deformed lherzolites and $\mathrm{Cr}$-poor discrete nodules may imply heating of the wall rock (garnet therzolite) by an intrusive magma which crystallized 
the Cr-poor discrete nodules. However, a straightforward transformation of coarse $\rightarrow$ deformed $\rightarrow \mathrm{Fe}-\mathrm{Ti}$ enriched deformed therzolites is not probable because some of the deformed lherzolites are more magnesian than some of the coarse ones. Hence the relationship of coarse and deformed lherzolites and $\mathrm{Cr}$-poor discrete nodules is still uncertain.

\section{REFERENCES}

Boyd, F.R., P.H. Nixon, and N.Z. Boctur, 1981: Ann. Rev. Dir. Geophys. Lab., 80, 328-336.
BovG, F.R., and P.H. Nixon, 1973: Lesotho Kimberlites, $254-268$.

Eggler, D.H., Y.E. McCallum, and C.B. Smith, 1979: The Mantle Sample, 213-226.

Hosserty, S.E., 1975: Phys. Chem. Earth, 9, 295-307.

lindslev, D.H., and S. A. Dixon, 1975: Am. J. Sci. $276,1285-1301$.

Perkins, D. III, and R.C. Newton, 1980: Contrib. Mineral. Petrol., 75, 291-300.

Robey, J., and J.J. Gurney, 1979, Kimberlite Symposium $[\mathrm{I}$, Cambridge.

s.chulze, D.J., 1981 , EOS, 62, 414.

Sclulze, D.J., and J.D. Hoover, 1982, EOS, 63.

\section{COMPOSITIONAL AND TEXTURAL FEATURES OF PERIDOTITE NODULES FROM THE JAGERSFONTEIN KIMBERLITE PIPE, SOUTH AFRICA}

Ben HARTE', John J. GURNEY²

'Grant Institute of Geology, University of Edinburgh. Scotland.

${ }^{2}$ Dept. of Geochemistry, University of Cape Town, South Africa.
Examination in the fleld of large $(>8.0 \mathrm{~cm})$ nodules at a variety of locations around the Jagersfontein mine area reveal that about $80 \%$ are coarse-grained peridotites with no obvious fabric or modal layering. The majority of these nodules are close to being harzburgites with only traces (1n hand specimen) of other phases, though there are trans1tions to peridotites with ca. 5\% clinopyroxene and/or garnet. Dunites, pyroxenites and ecologites form together about $5 \%$ of large nodules. The remainder (ca. $15 \%$ ) of the large nodule population is essentially formed by deformed peridotites (porphyroclastites or flaser gneisses in hand specimen), which differ modally from the coarse peridotites in commonly belng garnet-1herzolites with conspicuous ( $>5 \%$ ) clinopyroxene and garnet. Counts of small nodules $(<8.0 \mathrm{~cm})$ show a higher proportion (ca. 35\%) of deformed peridotites, but maintain the bias to harzburgitic assemblages in coarse peridotites and to garnet-lhezolites amongst deformed peridotites.

\section{Coarse Peridotites}

Microscopic and chemical-analytical investigations show that many of the coarse peridotites have detailed petrological affinities to one another. Olivine and orthopyroxene are always the dominant modal phases, but minor amounts of: clinopyroxene, garnet, amphibole, and chromian spinel also commonly occur. Often only two of these additional minerals occur as primary phases, but all combinations have been found including the six-phase assemblage: olivine + orthopyroxene + clinopyroxene + garnet + amphibole + Crspinel. A feature of many coarse nodules is the presence in the orthopyroxene of exsolution lamellae of spinel, which may be accompanied by fine birefringent exsolution lamellae (probably of clinopyroxene) and also garnet lamellae. Exsolution lamellae range up to about $0.1 \mathrm{~mm}$ across. Sometimes garnet, and to a lesser extent spinel, form small grains orientated along grain boundaries and arranged in partial "necklets' reminescent of granular exsolution. Another feature is the occurrence of occasional vermicular intergrowths of clinopyroxene and spinel in some garnet-free rocks.

The amphibole is an edentic hornblende (Leake 1978) and 1 ts relatively widespread though not abundant occurrence at Jagersfontein (first reported by Johnston 1973) is unusual by comparison with peridotite nodules from other kimberlites. In general, coarse-nodule mineral compositions are tightly restricted. Some features are shown in $\mathrm{Ca}: \mathrm{Mg}: \mathrm{Fe}$ projection in figure 1 . The $\mathrm{Al} / \mathrm{Al}+\mathrm{Cr}$ ratios are: $62-72 \%$ in clinopyroxene, $86-90 \%$ in amphibole, $90-94 \%$ in garnet, and $28-54 \%$ in spinel. $\mathrm{Mg} /(\mathrm{Mg}+\mathrm{Fe})$ ratios in orthopyroxene are 95$91 \%$, and $68-56 \%$ in spinel. $\mathrm{Al}_{2} \mathrm{O}_{3} \mathrm{wt} \%$ in orthopyroxene varies up to $3.3 \%$ in garnet-free assemblages, but is close to 0.65 in garnet-bearing rocks. In two thin sections exsolution lamellae of spinel and garnet in orthopyroxene gave virtually identical compositions to those of independent grains. In the clinopyroxene- spinel symplectites mineral compositions are also close to those of independent grains, as found in similar intergrowths by Dawson and Smith (1975). One unusual garnet harzburgite shows zoning of olivine and orthopyroxene compositions with variation of 93 to $89.5 \% \mathrm{Mg} /(\mathrm{Mg}+\mathrm{Fe})$ in the olivine, and corresponding variation in the orthopyroxene together with minor increases in $\mathrm{Ca}$ and $\mathrm{Al}$. The garnet compositions in this rock are constant, and 1 t is suspected that the rock underwent contamination (or metasomatism) in contact with melt.

The common coarse nodules which appear to form part of a coherent group were probably sampled from a restricted region of the upper mantle. They appear to have originated at high temperatures and cooled very slowly (possibly whilst depressurisation occurred) to allow the exsolution to proceed and the intergrowth compositions to maintain approximate equilibrium with all phases. $\mathrm{Ca} /(\mathrm{Ca}+\mathrm{Mg})$ ratios in clinopyroxenes are uniformly close to $50 \%$ and temperatures indicated by $\mathrm{Fe} / \mathrm{Mg}$ distribution in coexisting garnet and clinopyroxene (Mori and Green 1978) are in the range 800$875^{\circ} \mathrm{C}$. The mineral equilibria had probably become frozen prior to sampling by the kimberlite (Harte and Freer, this volume).

Deformed Peridotites

These nodules fall predominantly into the porphyroclastic and mosaic-porphyroclastic groups of Harte (1977). Some of the mosaic-porphyclastites also show laminar and fluidal textures. Also included in this group are occasional nodules which are transitional between coarse and porphyroclastic textural types, and some which show fine to medium grained granuloblastic textures (perhaps indicating complete recrystallisation and grain growth after deformation). Garnet and clinopyroxene are common phases in addition to olivine and orthopyroxene, but amphibole and spinel have not been found as primary independent phases. However, fine exsolution lamellae of spinel appear to be present within orthopyroxene porphyroclasts in a few nodules.

Mineral compositions are more variable in this group than in the coarse nodules. In addition to the features shown in figure 1 it may be noted that $\mathrm{Al} /$ $(\mathrm{Al}+\mathrm{Cr})$ varies from 45 to $90 \%$ in clinopyroxenes, and from 65 to $97 \%$ in garnets. The range of $\mathrm{Al}_{2} \mathrm{O}_{3}$ in orthopyroxene is however quite restricted between 0.45 and 1.11 wt \%: whilst $\mathrm{Mg} /(\mathrm{Mg}+\mathrm{Fe})$ in this phase varies from 93 to $88 \%$. In most rocks the mineral compositions are homogeneous, but in two cases the olivine and orthopyroxene neoblasts show marginally higher Fe/ $\mathrm{Mg}$ than the porphyroclasts. Temperature estimates, using $\mathrm{Fe}-\mathrm{Mg}$ distribution between garnet and clinopyroxene (Mori and Green 1978), show a range of 1140 to $1380^{\circ} \mathrm{C}$ for the deformed nodules. But some nodules show a lack of correspondence between different geothermometers, which may indicate some disequilibrium. The wide spread of temperature estimates is unusual 